\title{
Research Article \\ Physiological and biochemical evaluation of varagu with blackgram intercropping competition and yield advantage
}

\author{
K.Ananthi and P. Parasuraman
}

\begin{abstract}
SUMMARY
Intercropping increases in productivity per unit of land via better utilisation of resources, minimises the risks, reduces weed competition and stabilizes the yield. Many intercropping systems have proved to be better than sole crops in terms of yield because intercropping makes better use of one or more agricultural resources both in time and in space. The beneficial effect of pulse crops is improving soil health in the form of biological nitrogen fixation, leaf fall, addition of considerable amount of organic matter through root biomass, improving microbial biomass and they keep soil productive and alive by bringing qualitative changes in physical, chemical and biological properties and sustaining productivity. The principal advantage of intercropping system is the more efficient utilization of soil, water, nutrient and increased productivity compared with each sole crop under rainfed and irrigated ecosystem. Choice of ecologically sound crops as millets and adoption of intercropping systems are two of suitable options for maximization of productivity in drylands cropping system due to the reason that competition of plant could be minimized not only by spatial arrangement, but also by combining those crops which have best able to exploit soil nutrients. A field study was scheduled to estimate the impact of intercropping varagu with greengram and blackgram cropping system under rain-fed situation onleaf area, leaf area index, specific leaf weight, crop growth rate, chlorophyll content, no. of tillers per plant and grain yield at Centre of Excellence in Millets, Athiyandal, Tiruvannamalai. It was done in Kharif, 2018 and 2019. Randomized Block Design was used to conduct this experiment. It has three replications. The aim of this study was to evaluate and compare varagu with blackgram and greengram inter cropping effects, as well as reveal which intercrops better adopts to rainfed cropping systems using these parameters to improve water use efficiency in the production. Highest returns were obtained from Sole Varagu with blackgram (1:1) due to greater productivity under this treatment with comparable cost of cultivation.
\end{abstract}

Key Words : Small millets, Intercropping, Specific leaf area, Chlorophyll content, Productivity

How to cite this article : Ananthi, K. and Parasuraman, P. (2021). Physiological and biochemical evaluation of varagu with blackgram intercropping competition and yield advantage. Internat. J. Plant Sci., 16 (2): 147-154, DOI: 10.15740/HAS/IJPS/16.2/147-154, Copyright @ 2021: Hind Agri-Horticultural Society.

Article chronicle : Received : 15.03.2021; Revised : 28.04.2021; Accepted : 17.05.2021

\section{MEMBERS OF THE RESEARCH FORUM}

Author to be contacted :

K. Ananthi, Department of Crop Physiology, Agricultural College and Research Institute, Vazhavachanur, Thiruvannamalai (T.N.) India

Email : ananthiphd@yahoomail.com

Address of the Co-authors:

P. Parasuraman, Regional Research Station, Paiyur (T.N.) India 